\title{
Forecasting the Money Multiplier: Implications for Money Stock Control and Economic Activity
}

\author{
R. W. HAFER, SCOTT E. HEIN and CLEMENS J. M. KOOL
}

NE approach to controlling money stock growth is to adjust the level of the monetary base conditional on projections of the money multiplier. That is, given a desired level for next period's money stock and a prediction of what the level of the money multiplier next period will be, the level of the adjusted base needed to achieve the desired money stock is determined residually. For such a control procedare to function properly, the monetary authorities must be able to predict movements in the multiplier with some accuracy, ${ }^{1}$

This article focuses, first, on the problem of predicting movements in the multiplier. Two models' capabilities in forecasting the $\mathrm{Ml}$ money multiplier from January 1980 to December 1982 are compared. One procedure is based on the time series models of Box and Jenkins. ${ }^{2}$ The other model, a more general one, is

Scott E. Hein is an associate professor of finance at Texas Tech University, and Clemens $J$. $M$. Kool is an assistant professor of economics at Erasmus University, Rotterdam, The Netherlands. This article was writfen while Professor Hein was a senior economist at the Federal Reserve Bank of St. Louis.

${ }^{1}$ One of the earlier attempts to develop a multiplier forecasting model is presented in Albert E. Burger, Lionel Kalish III and Christopher T. Babb, "Money Stock Control and lts Implications for Monetary Policy," this Review (October 1971), pp. 6-22. More recent attenpts, which almost exclusively have used some form of time-series nodel, are represented by Eduard I. Bomhoff "Predicting the Money Multiplier: A Case Study for the U.S. and the Netherlands," Journal of Monetary Economics (July 1977), pp. 325-45, James M. Johames and Robert H. Rasche, "Predicting the Money Multiplier,"Journal of Monetary Economics (July 1979), pp. 301-25; H.-J. Buttler, J - F. Gorgerat, H. Schiltknecht and K. Schiltknecht, "A Multiplier Model for Controlling the Money Stock," Journal of Monetary Economics (July 1979), pp. 327-41; and Michele Fratianni and Mustapha Nabli, "Money Stock Control in the EEC Countries, "Weltwitschaftiches Archiv (Heft 3: 1979), pp. 401-23.

${ }^{2}$ For an indepth discussion of these models, see George E. P. Box based on the technique of Kalman filtering. ${ }^{3}$ Although the Box-Jenkins type of model has been used in previous studies to forecast the M1 multiplier, this study is the first to employ the Kalman filtering approach to the problem.

The second purpose of this study is to use the multiplier forecasts in a simulation experiment that implements the money control procedure cited above. Given monthly money multiplier forecasts from each of the forecasting methods, along with predetermined, hypothetical M1 growth targets, monthly and quarterly Ml growth rates are simulated for the 1980-82 period.

Finally, the importance of reduced volatility of the quarterly $\mathrm{M} 1$ growth is examined in another simulation experiment. Using a reduced-form "St. Louis" GNP equation estimated through IV/1979, nominal GNP is simulated for the 1980-82 period using actual $M 1$, desired $M 1$ and the $M 1$ growth rates derived from our forecast/control procedure simulation. The outcome shows that the volatility of simulated GNP growth during the 1980-82 period is halved when the M1 growth simulated from our forecast/control procedure is used in place of actual M1 growth. This finding indicates that, other things equal, reducing the

and Gwilym M. Jenkins, Time Series Analysis, Forecasting and Control (Holden-Day, Inc., 1970).

"Kalman Nttering was introduced first in the fleld of engineering. See R. E. Kalman, "A New Approach to Linear Filtering and Prediction Problems," Journal of Basic Engineering (1960), pp. 34 45; and R. E. Kalman and R. S. Bucy, "New Results in Linear Filtering and Prediction Theory, Journal of Basic Engineering (1961), pp. 95-108. For an introduction to Kalman filtering, see Richard J. Meinhold and Nozer D. Singpurwalla, "Understanding the Kalman Filter," The American Statistician (May 1983), pp $123-27$. 
quarterly volatility of money growth would tend to produce more stable economic growth.

\section{THE MULTIPLIER FORECASTING MODELS}

\section{Box-Jenkins Model}

The first forecasting strategy considered is based on the techniques of Box and Jenkins (hereafter BJ). This approach requires the identification and estimation of the appropriate model before predicting the money multiplier. A consideration of the autocorrelation and partial autocorrelation function suggested an ARIMA $(0,1,1)$ process. Estimating this model for the period January 1959 to December 1979 yields the following relationship:

(l)

$$
\begin{gathered}
\mathrm{m}_{\mathrm{t}}-\mathrm{m}_{\mathrm{t}-\mathrm{l}}=\begin{array}{c}
-0.002+0.263 \varepsilon_{\mathrm{t}-1}+\varepsilon_{\mathrm{t}} \\
(-4.40) \quad(4.31)
\end{array} \\
\mathrm{SE}=0.011 \quad \mathrm{Q}(30)=41.5
\end{gathered}
$$

where $m_{t}$ is the MI multiplier (M1 divided by the adjusted monetary base), $\varepsilon_{\mathrm{t}}$ is the unforeseen current shock to the change in the multiplier, $\varepsilon_{t-1}$ is the unforeseen shock to the change in the multiplier last period, and the value -0.002 is a negative drift in the level of the multiplier. ${ }^{4}$

Equation I suggests that changes in the multiplier can be explained partially by the error in the multiplier process last month $\left(\varepsilon_{\mathrm{t}-1}\right)$. The reported $\mathrm{t}$-statistic, which appears in parentheses below the respective coefficient estimate, reveals that last month's error exerts a statistically significant effect on the current change in the multiplier. Moreover, the constant term reveals a slight negative, but statistically significant, trend in the level of the multiplier. Finally, the Qstatistic indicates that the model's residuals pass the test for white noise. ${ }^{5}$ The moving-average model given by equation 1 will be used subsequently to forecast the Ml multiplier.

\footnotetext{
"This model was identified from an examination of the antocorrelation derived from the level and first difference of the multiplier The first-difference specification was chosen because the antocorrelations of the level series did not display the stationarity characteristic necessary to properly andyze time series.

The Q-statistic is used to determine if the estimated model has transformed the error series into whize noise. Since the reported $Q$-statistic is less than the critical $\chi^{2}$ value at the 5 percent level (43.8), one cannot reject the hypothesis of white noise resibuals and, therefore, the appropriateness of the estimated model.
}

\section{Kalman Filter Model}

Multiplier forecasts also are derived from a general Kalman filtering model, the so-called Multi-State Kalman Filter (MSKF) method. ${ }^{6}$ This technique is described in more detail in the insert.

The MSKF model used here is a set of four parallel models, each equivalent to a different ARIMA $(0,1,1)$ specification with the coefficients fixed $a$ priori. These models are used to simultaneously distinguish among four types of shocks to the multiplier: small or large, temporary or permanent. Thus, unlike the BJ procedure, the MSKF technique tries to identify the nature of the different shocks and use this information in forecasting. Given this period's prediction error and given the "state" of the system represented by all former information, the MSKF algorithm determines the probability that the shock was large or small, the proportion of this forecast error that should be viewed as temporary, and the portion that is likely to be permanent. Once this evaluation is made, the probabilities associated with the four different states are revised, and the weights associated with each are adjusted accordingly. In this way, the MSKF method allows the forecaster to reassess the structure of the forecasting model as new data become available.

Since the BJ method has been shown to work well and the MSKF procedure appears more flexible in evaluating new information, the MSKF method should be useful in forecasting the multiplier.

\section{FORECASTING THE MULTIPLIE USING BOX-JENEINS AND MSKF MTHODS}

The M1 multiplier was forecast, ex ante, for the period January 1980 to December 1982 using the BI and MSKF models. In each case, the forecasts are

\footnotetext{
${ }^{6}$ Development of this method is presented in D. 1 . Harrison and $\mathrm{C}$. E. Stevens, "A Bayesian Approach to Short-Term Forecasting," Operational Research Quatterly (4:1971), pp, 341-62, and "Bayesian Forecasting," Journal of the Royal Statistical Society (3:1976), pp. 205-47. Applications are found in Eduard I. Bomhoff, "Predicting the Price Level in a World that Changes All the Time," in Karl Brunner and Allan H. Meltzer, eds., Economic Policy in a World of Change, Carnegie Rochester Conference Series on Peblic Policy (Autumn 1982), pp. 7-38; Eduard I. Bomboff and Clemens I. M. Kool, "Learning Processes and the Choice Between Abrupt and Gradual Counter-Inftation Policies," unpublished manuscript, Erasmus University (May 1982): and Edaard J Bomboff and Pieter Korteweg, "Exchange Rate Variability and Monetary Policy Under Rational Expectations: Some EuroAmerican Experience, 1973-1979," Journal of Monetary Economics (March 1983), pp. 169-207.
} 


\section{Exposition of the MSKF Model}

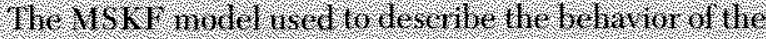

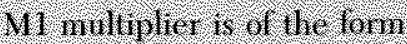

(A) $m_{i} \cdot n_{1}+4$

and

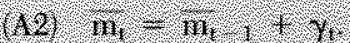

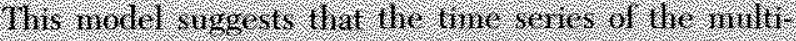

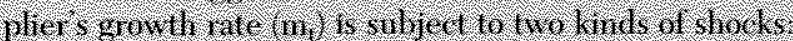

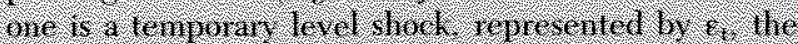

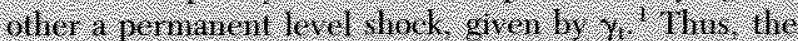

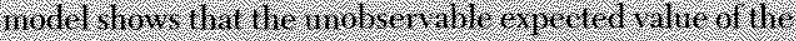

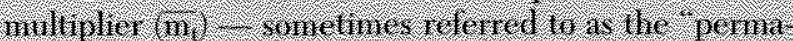

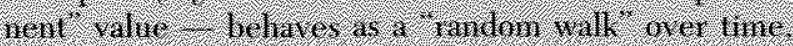

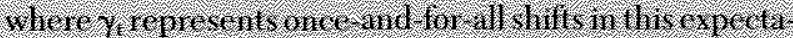

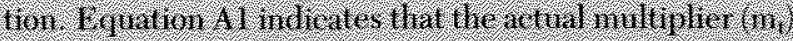

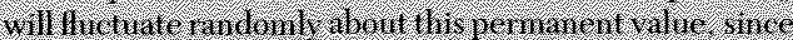

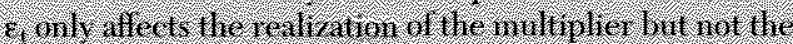
tinderiving e roctition.

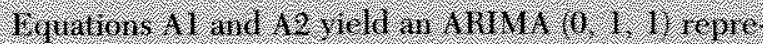

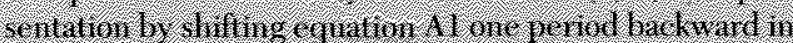

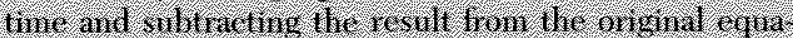

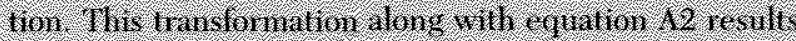
11

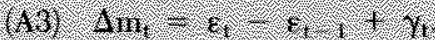

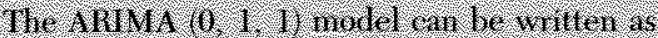

(1) $\mathrm{m}_{1}$

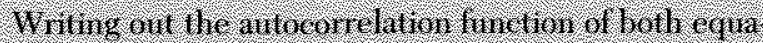

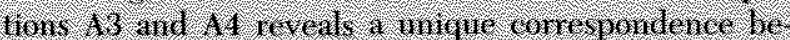

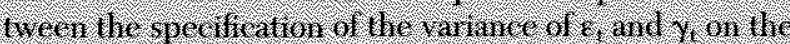

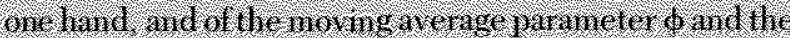

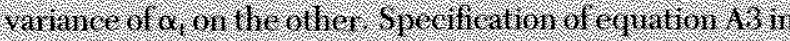

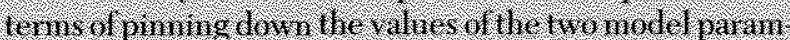

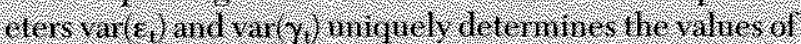

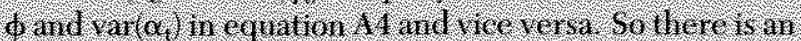

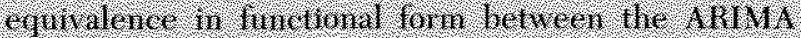

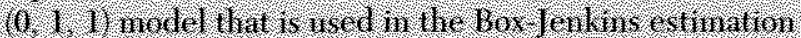

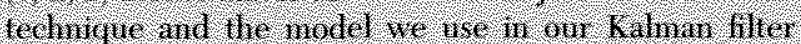

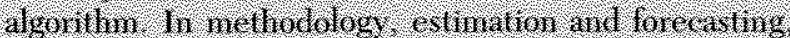

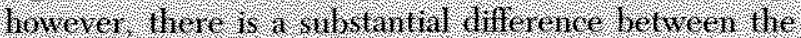

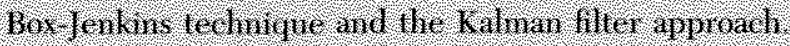

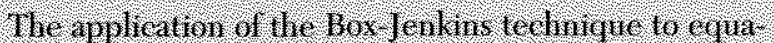

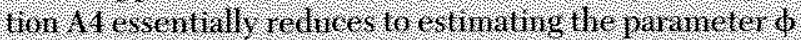
and lle varince of a, boll of which are assinned to be

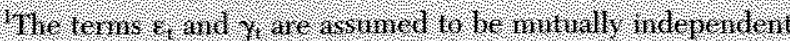

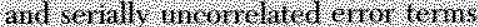

\section{Table A1}

\section{Model Specification}

\begin{tabular}{|c|c|c|c|c|}
\hline Model & 0 & Varren & Var(x) & $\operatorname{lar}(0,0$ \\
\hline Small teroporary & 0.95 & 095 & 0.0025 & 1 \\
\hline Small permanclo & 006 & 005 & 0.9025 & ? \\
\hline Large lemporan & 0,99 & 17884 & 0.0016 & 16 \\
\hline l arge pernanent & 0.07 & 80.16 & 15.6016 & 16 \\
\hline
\end{tabular}

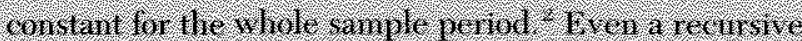

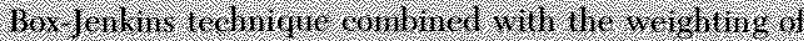

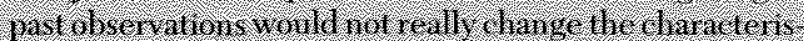

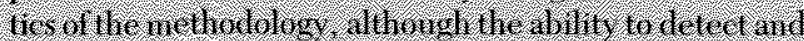

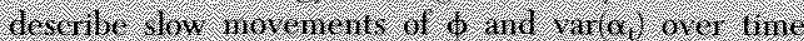

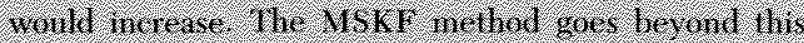

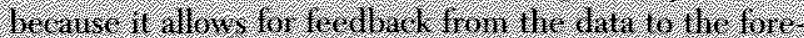

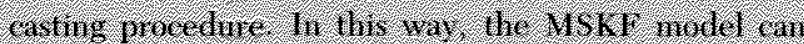

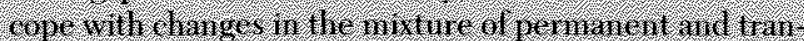

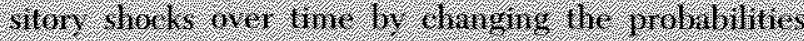

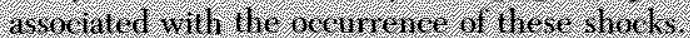

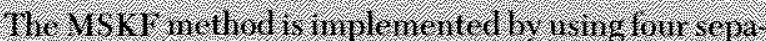

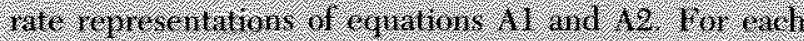

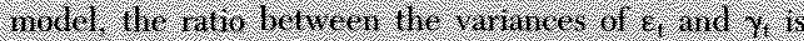

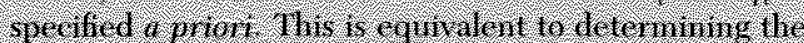

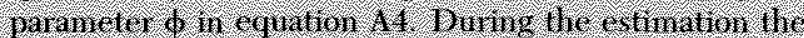

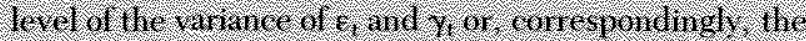

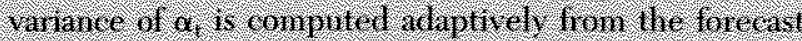

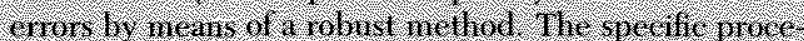

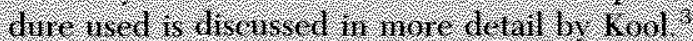

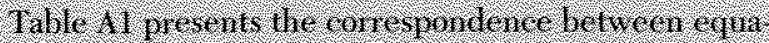

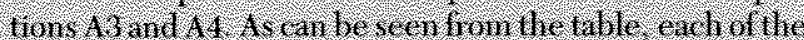

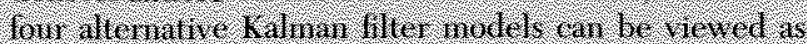

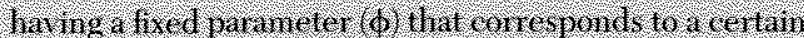
thine se ties process. 1 sims equation 14 , 1 he oxpertations

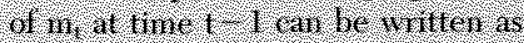

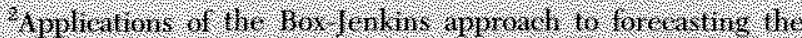

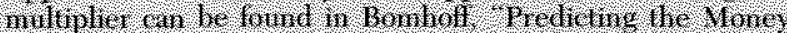

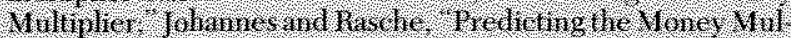

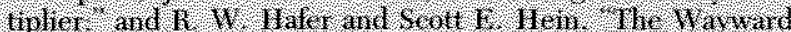

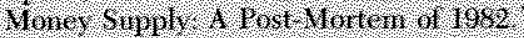

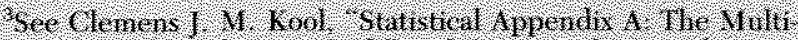

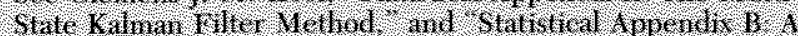

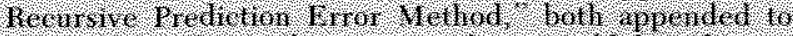

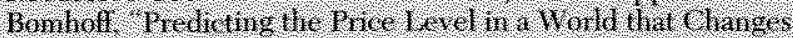

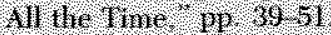


(A5)

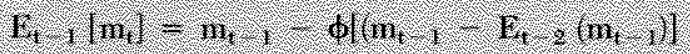

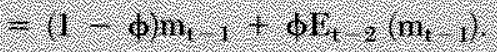

Thiss, for each model the expectition of next periods in is i verghted average of the last olsserved value in. and he prediction for in, inade at thet -2 . The lower the value of $\phi$, the more weight is given to the observed value in, and the nore problible it is that the difference

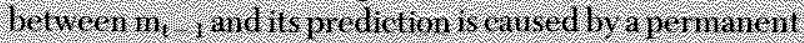
shitt A high value of $\phi$, on the other hand, indicates that there is a ligh probahility that diferences between $n_{\text {t }}$. and its expectation are of a nore tenporaty nature In this case, if is best to largely: ighore these prediction errors and not to incorporate therin into nete penuds predietion. The first model in the table At the small tenporary shock nodel is sud a represcitation It has a 6 parameter vistue of 095 indicating that ony 5 percent of this periods prediction error is incomporated in next periods forectist:

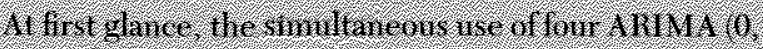
1. 1 models each with and prionifixed coeficent does not stem to be a great improvenent conmiret with a fres estimation of that moving a wer ge paraneter by means of the Box-Jenkins nethed. There is rognt to improvenent.

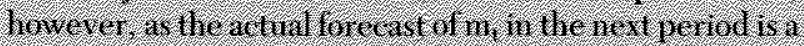
verulited forecast of the four Kalman liter nodels used. The weight attached to each of individual wodels for next period's prediction is e cual to die (postenon) mebalility that the multipliet procese at that noment in time is indeed described hy that model. These weights can vary consid rably over time and ex en from period to period Morcover, the kilman filter composite forrcast can lie described as the forecast of a single ARIMA nodel with

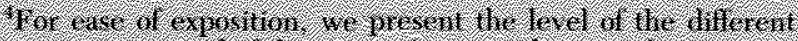

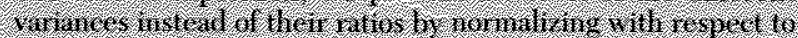

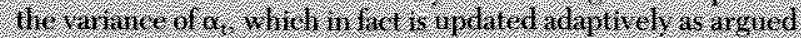

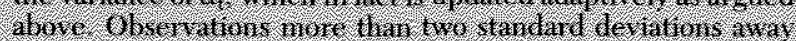

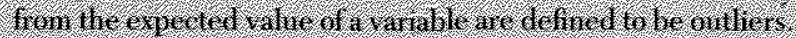

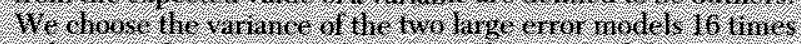

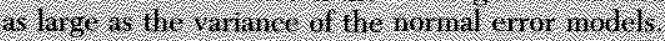

the parameter free to change from period to period st in this respect, the use of four fxed rnodels in fiet increases the fexibility of the nethod in describing the nutiplier process:

The feedback from data to the forecasting nodels provides us wilh a tool to ald in forecasting a given tme series The data provide information on both the pesterior werghts of the respective nodels and on the current whe of the parameter $d$. Whiel is relevant for lorecasting next perids multiples the flat also fontain information conceming the probabilites that each nodel will atequalely deseribe the nultipliers bethevior in the frture: in general. if is true thist the prohahility - posterior to the ohservation of the nultiplier value n periodt - that model is describing the nimiplier proces conrect, is calculated as a combination of the o mioni mobibility at tine - I that model will le the right inodel to describe the process in period t and the infomaten contwined in 6hoservatim no. 7 iis combination determines the posteror urotahility for each nodel and at the same tine the Meright of each nodet in next permod s. forecast

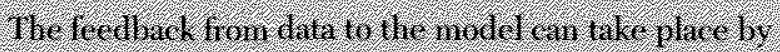
is ing the data a sectond time looking baek at period t 1 alter the observation of the mithiplier valine in period t. It is dights withatle that the combined niformation of olser ations of periodst 1 and 1 will give a better eval. tation of the state of the process in perind t - 1 than the abservation of period 1 - I lone. So the posterior prob. dhilites for period 1 - 1 are rectculated, using the ofsernation at tine I. These recalcitated frolabihites then are used lo adjust the protuiling prior protblilties. The pror probabilities for the vamins nodels tan be arid to be updated adaptively over time as new othervations become avalable, there by wifluencing fintire forecaste.

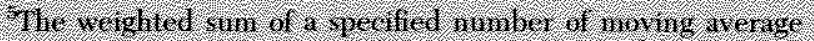

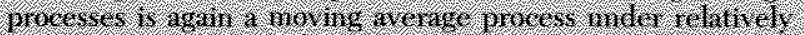

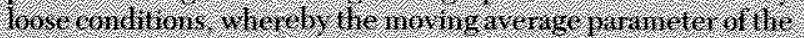

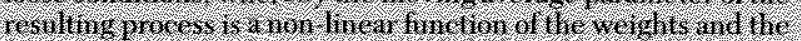

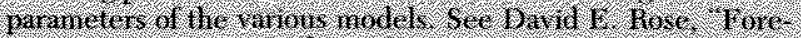

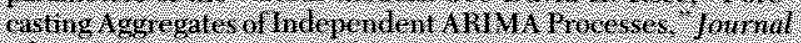

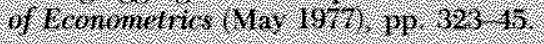

one-step-ahead predictions of the multiplier, based on data through the most recent month. ${ }^{7}$ Specifically, suppose a forecast for the June 1981 money multiplier is desired. Given the parameter estimates in, say, equation 1, the data through May 1981 are used to

This procedure is used in R. W. Hafer and Scott E. Hein, "The Wayward Money Supply: A Post-Mortem of $1982, "$ this Review (March 1983), pp. 17-25. See also Anatol B. Balbach, "How Controllable is Money Growth?" this Review (April 1981), pp. $3-12$. construct the June forecast. This data set is then updated to include June to construct the July forecast, and so on. By continually updating the information set available to the forecaster, the procedure used here closely imitates the process by which a policymaker actually would generate multiplier forecasts.

Chart I plots the multiplier forecast errors (actual minus predicted multiplier) for each of the two procedures. As shown there, the errors follow a similar pattern during the sample. The forecast error derived 
from the MSKF procedure is closer to zero, on average, than using BJ. The largest forecast errors for both models come in March-April 1980. During this period, when special credit controls were enacted by the Carter administration, the actual multiplier fell sharply from 2.603 in February 1980 to 2.578 in March and 2.524 in April. This decline, though small in absolute magnitude, is quite large compared with other changes in the multiplier.

To assess further the relative capabilities of the two forecasting procedures, summary forecast statistics for 1980 to 1982 are presented in table 1. Turning first to the full-period results, the notion that the MSKF procedure, on average, produced better forem casts than the BJ model is corroborated statistically: the mean error (ME) from the MSKF model is 75 percent smaller than the mean error from the BJ model. In both cases, however, the mean error is quite small, indicating very little bias in either forecasting procedure. Indeed, the Theil decomposition statistics indicate that less than 5 percent of the forecast error is due to bias $(B)$. Further, there is a 13 percent reduction in the mean absolute error (MAE) and a 9 percent reduction in the root-mean-squared error (RMSE) for the MSKF procedure relative to the BJ approach. Thus, the evidence in table 1 demonstrates the relative superiority of the MSKF procedure over the BI method in forecasting the multiplier.

The full-period results indicate that an improvement in the multiplier forecasts can be attained by using the MSKF procedure. This improvement, gauged on a year-by-year basis, varies. For example, in 1980 the reduction in RMSE gained by using the MSKF model is 4 percent; in 1981 it is 26 percent; in 1982, 15 percent. The characteristics of the forecast errors also vary from year to year. For example, in 1981 bias accounted for 42 percent of the BJ forecast error, compared with only 17 percent for the MSKF model. While in 1982 the fraction of error due to bias was reduced for the $\mathrm{BJ}$ model from the previous year, this fraction is still higher than that of the MSKF model and, as chart 1 indicates, the BJ procedure underpredicted the actual multiplier more often than the MSKF model.

Given the behavior of the money multiplier, the improved relative performance of the MSKF model in 1981 and 1982 is not too surprising. As indicated in chart 2, 1981 and 1982 were the forst years since $1959 \mathrm{in}$ which the money multiplier grew. Over the previous years, there was a consistent negative trend in the multiplier. As we saw before, this trend is significant in the $\mathrm{BJ}$ model $(-0.002)$, and its assumed continuation
Eład I

Box-Jenkins and Multi-State Kalman Filter

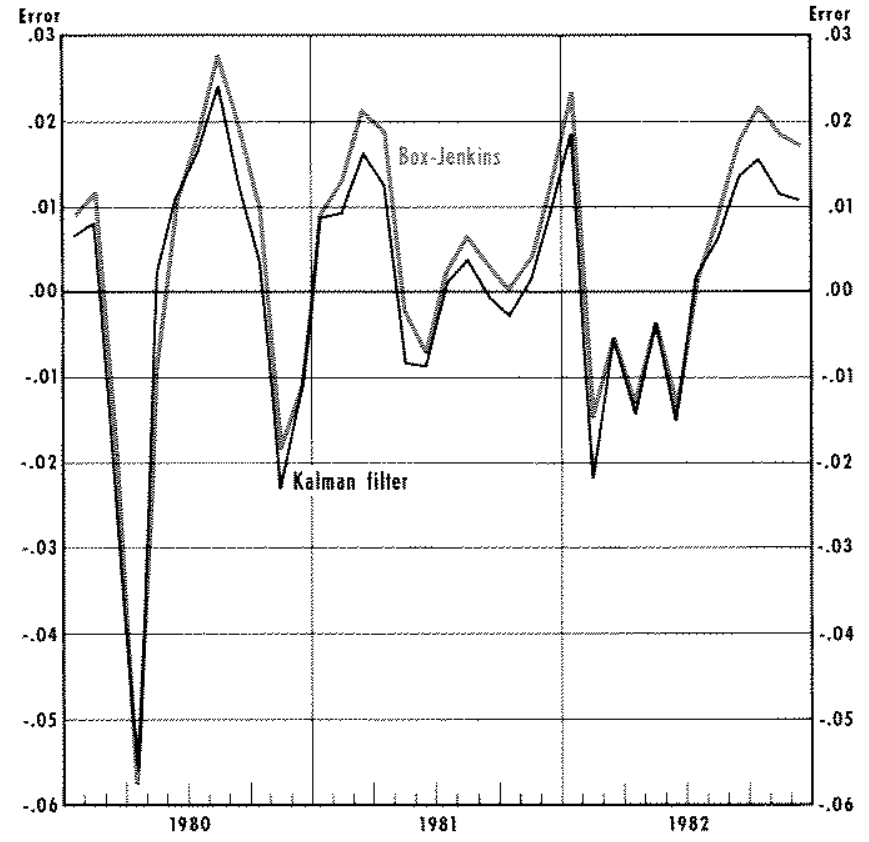

marks this forecast procedure. Because the multiplier did not continue to decline, the BJ forecast underpredicted quite frequently.

As suggested, the MSKF model adapts more easily and more rapidly to changing conditions. Thus, it is not too surprising that the MSKF model tends to underpredict the money multiplier less than the BJ model. Probably the most striking feature of the forecasts, given the sharp break in the multiplier trend, is the small degree of bias derived from either forecast procedure.

The forecast evidence on the whole indicates that the MSKF model provides relatively more accurate one-step ahead forecasts of the money multiplier than the BJ model. It should be noted, however, that this improvement is small relative to the absolute forecast errors. Even so, the evidence suggests that more aceurate forecasts of the multiplier can be made; we now consider the policy relevancy of this finding.

\section{MONEY GRONTWI: 1980-82}

The growth of the money stock during the past few years has been the subject of heated debate. Some have argued that the large swings in money growth 


\section{Table 1}

Summary Statistics for One-Step-Ahead Multiplier Forecasts: January 1980-December 1982

\begin{tabular}{|c|c|c|c|c|c|c|c|c|}
\hline \multirow{2}{*}{ Suminary } & \multicolumn{2}{|c|}{$1 / 1980 \div 12 / 1982$} & \multicolumn{2}{|c|}{$11980-12,1980$} & \multicolumn{2}{|c|}{$1,1981-121968$} & \multicolumn{2}{|c|}{$11982-12 / 1982$} \\
\hline & B) & nswe & $\mathrm{m}$ & Msur & Bu & nskr & (6) & Msure \\
\hline $\mathrm{Me}$ & 000086 & 00009 & 00009 & 00023 & 0.0068 & 00005 & 0.0048 & 100015 \\
\hline MAE & 00184 & 0.0116 & 0.0185 & 100165 & 0.0083 & 0,0069 & 00132 & 0.0115 \\
\hline nMse & 000168 & 0.0153 & 00226 & 00216 & 000106 & 0.0084 & 0.0148 & 00129 \\
\hline U & 00065 & 0.0059 & 00088 & 0.0084 & 0.0041 & 00003 & 00058 & 00050 \\
\hline 8 & 0.0459 & 0.0095 & 0.0015 & opolle & 044200 & 0,1741 & 01049 & 00132 \\
\hline \% & 000228 & 00021 & 0,0061 & 00009 & 0.0332 & 0.0954 & 0.0549 & 0.0262 \\
\hline 9 & 09314 & 0.9944 & 0.9924 & 098679 & 0.5468 & 0.7305 & 0.0402 & 0.9606 \\
\hline
\end{tabular}

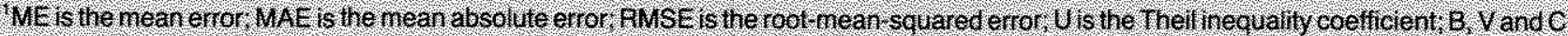
represent the amount of forecast error due to bias, variation and covariation, respectuvely between actual and lorecasted seties.

Char: 2

Level of the M1 Money Multiplien

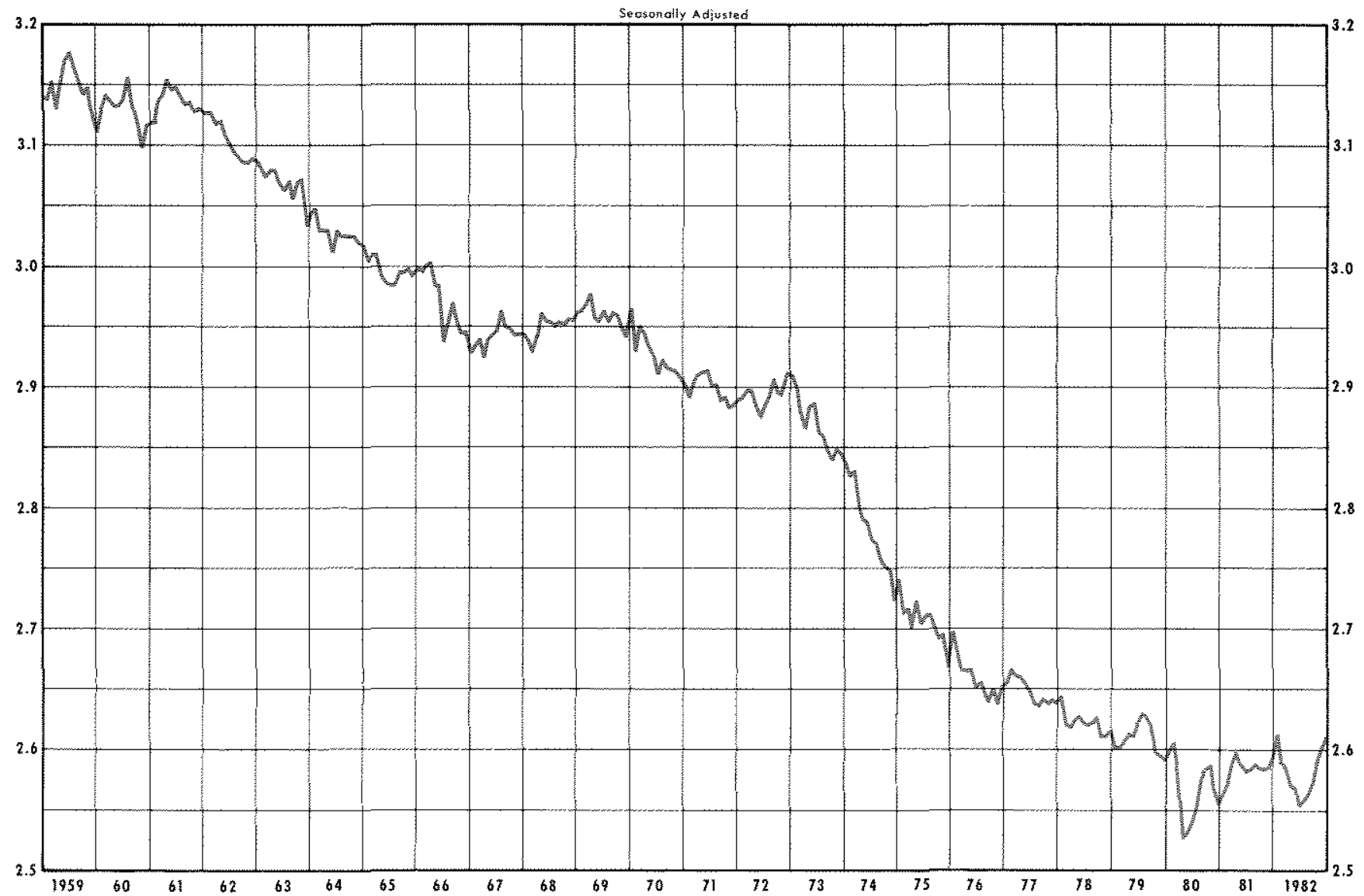


resulted from erratic changes in the public's demand for money, ${ }^{8}$ Others have suggested that certain technical changes, such as implementing contemporaneous reserve accounting, revising discount rate policy and the restructuring of reserve requirements, must be made in order to better control the money stock.

Table 2 reports the monthly and quarterly growth rates of M1 for the period January 1980 to December 1982. The monthly growth rates indicate a significant degree of variability in the series. During 1980 , for example, the average monthly growth rate for $\mathrm{Ml}$ was 7.18 percent with a standard deviation of 12.50 percent. This relatively high degree of variability is due primarily to the large downturn in money growth dur ing the February-April period when the special credit controls were implemented.

The years 1981 and 1982 show a reduction in money growth variability. In 1981, the average monthly growth of M1 declined to 6.56 percent with a standard deviation of 5.97 percent. In 1982, average monthly money growth and variability, although smaller than 1980, showed some increase over 1981: money growth averaged 6.56 percent with a standard deviation of 6.80 percent.

The quarterly growth rates in table 2 also indicate an erratic pattern to money growth. During the three years examined, the standard deviations of quarterly MI growth are 8.60 percent in $1980,2.85$ percent in 1981 and 4.71 percent in 1982.

\section{SWMULATHG MONEY GROW}

It has been argued that policymakers could achieve a more stable pattern of quarterly money growth by implementing the following control procedure:

1) In period t, using all available information, a forecast of the money multiplier for period $t+1$ is made.

2) Given this forecast and the level of M1 desired in $t+1$, the amount of adjusted monetary base to support that money stock is determined, and the base is changed to achieve this new desired level. Thus, any deviation of the money stock from the desired level

\footnotetext{
${ }^{8}$ This view is disputed in Scott E. Hein, "Short-Run Money Growth Volatility: Evidence of Misbehaving Money Demand," this Review (June/July 1982), pp. 27-36; Kenneth C. Froewiss, "Speaking Softly But Carrying a Big Stick," Economic Research (Goldman Sachs, December 1982); and John P. Judd, "The Recent Decline in Velocity: Instability in Money Demand or Inflation?" Federal Reserve Bank of San Franciseo Economic Review (Spring 1983), pp. 12-19.
}

Table 2

M1 Growth Rates: 1980-82

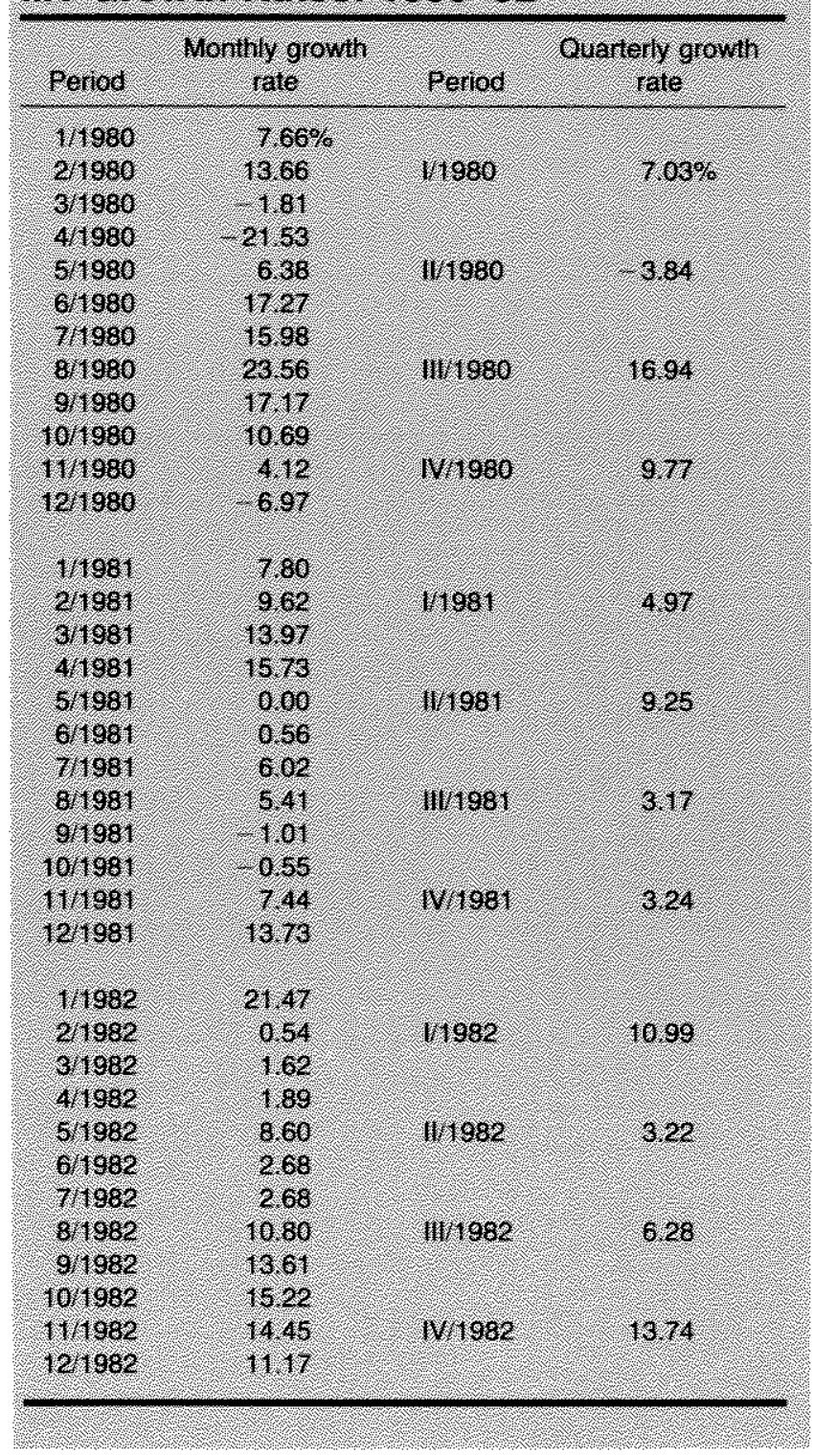

is the result solely of a money multiplier forecast error.

3) In period $t+1$, the forecast of the multiplier is recalculated for $t+2$, taking into account money multiplier information available through period $t+1$.

4) Again in $t+1$, the adjusted base necessary to achieve the desired money stock in $t+2$ is calculated.

The process continues month by month, always attempting to achieve the desired level of money stock. Clearly, an accurate money multiplier prediction is important for this control procedure to achieve the 
Table 3

Simulating M1 Growth Using Box-Jenkins Multiplier Forecast: January 1980-December 1982 (seasonally adjusted)

\begin{tabular}{|c|c|c|c|c|c|c|c|}
\hline \multirow[b]{2}{*}{ Perrod } & \multirow{2}{*}{ Targeted } & \multirow{2}{*}{ 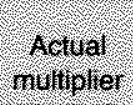 } & \multirow{2}{*}{$\begin{array}{l}\text { Forecasted } \\
\text { malfolier }\end{array}$} & \multirow{2}{*}{$\begin{array}{l}\text { Simuled } \\
\text { Gase }\end{array}$} & \multirow{2}{*}{$\begin{array}{l}\text { Simulated } \\
\text { Mr }\end{array}$} & \multicolumn{2}{|c|}{ Sinulared wh grovth rale } \\
\hline & & & & & & Wonthy & Quareny \\
\hline $1 / 1960$ & $\$ 3907$ & 2.5955 & 25866 & 8151.0 & 3392.0 & $9.67 \%$ & \\
\hline $2 / 960$ & 3923 & 26026 & 25909 & .8514 & 394 & 6.63 & $3.82 \%$ \\
\hline 3.1980 & 3940 & 25780 & 2.5973 & 1517 & $1391 \%$ & .870 & \\
\hline 41960 & 3957 & 25235 & 25811 & 1,838 & 3869 & 1235 & \\
\hline 5,1000 & 9974 & 25266 & 25364 & 1567 & 8956 & 81.76 & 211 \\
\hline 6980 & 8991 & 25373 & 25270 & 1579 & $400 \%$ & 15.77 & \\
\hline 71980 & 4008 & 25508 & 25024 & 150.8 & 4087 & 9.62 & \\
\hline $8 / 1980$ & 4025 & 25716 & 25437 & 1502 & 4069 & 9.95 & 1216 \\
\hline 9.1080 & 4042 & 25812 & 25620 & 1578 & 4072 & 1,02 & \\
\hline 10,1980 & 4660 & 25837 & 25739 & 1577 & 4075 & 0.72 & \\
\hline 1111980 & 4077 & 25605 & 25789 & $(58.1$ & 4048 & .770 & 0.65 \\
\hline $12 / 1980$ & 4094 & 25514 & 25632 & 1597 & 4075 & . 862 & \\
\hline 1,4901 & 4161 & 26612 & 25523 & 1630 & $47>6$ & 10.50 & \\
\hline 2,21981 & 4181 & 25698 & 23566 & 1636 & 420.3 & 815 & 5.10 \\
\hline 171901 & 420.2 & 258563 & 25641 & 1638 & 423.6 & 999 & \\
\hline $4 / 981$ & 4222 & 25964 & 25775 & 1638 & 4253 & 4.88 & \\
\hline 51981 & 4243 & 2,5870 & 25892 & 1609 & 4239 & 3.67 & 4. 19 \\
\hline 6.1981 & 1426. & 25789 & 25854 & 1649 & 4253 & .0 .90 & \\
\hline 71981 & 4284 & 25806 & 25784 & 1602 & 4288 & 1041 & \\
\hline $8 / 1981$ & 4306 & 25843 & 25776 & 4670 & $131 \%$ & 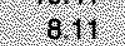 & $60 \%$ \\
\hline 91901 & 4326 & 25834 & 25804 & 1676 & 4364 & 432 & \\
\hline 101,901 & 4847 & 2.5807 & 25804 & $(685$ & 4348 & 466 & \\
\hline 111981 & 486.6 & 25824 & 25704 & 1604 & 4375 & 1781 & 629 \\
\hline 121061 & 4890 & 25918 & 25791 & 1702 & 44,1 & 10.37 & \\
\hline 11982 & 4420 & 26096 & 25862 & 1709 & 4460 & 1585 & \\
\hline 271982 & 4435 & 25866 & 2.6012 & 170.5 & $4 \times 10$ & 1273 & 6.64 \\
\hline 71982 & 444.9 & 258826 & 25882 & $17 / 19$ & 4440 & 8.42 & \\
\hline 419982 & 4464 & 25689 & 2.5819 & 1729 & 4442 & 0.46 & \\
\hline $5 / 1982$ & 4479 & 25661 & 25701 & 1743 & 4472 & 844 & 220 \\
\hline $6 / 1982$ & 4493 & 25515 & 26649 & 1762 & 4470 & 0.49 & \\
\hline $7 / 982$ & 4506 & 2.5642 & 25528 & 1766 & 4511 & $(1) 51$ & \\
\hline 8,1982 & 458.8 & 25603 & 25616 & $17 \% 2$ & 450.6 & 47.62 & 720 \\
\hline 9,1982 & 450. & 25733 & 25558 & 1776 & 4569 & 8.66 & \\
\hline 101902 & 4552 & 25881 & 25665 & 774 & 4501 & 5.98 & \\
\hline 11,1002 & 4567 & 25987 & 25802 & 1770 & 4600 & 241 & 568 \\
\hline 121962 & 458.2 & 26088 & 25916 & 1768 & 46.3 & 3.37 & \\
\hline
\end{tabular}

Billons or dollars.

desired money stock objective. In this regard, the MSKF approach should yield a quarterly money stock series of lower variability than the BJ model.

Before examining the simulation results, it must be noted that the control procedure discussed here is not designed to reduce the monthly variability in $\mathrm{Ml}$ growth. The objective is to achieve a monthly target and, because the procedure attempts to correct errors in money growth each month, the month-to-month variability in the simulated growth rates may be large. An important feature of this control procedure, however, is that it alters the distribution of monthly growth rates in such a way that growth rate variability over quarterly or longer time horizons is likely to be reduced. Given existing empirical evidence on the rela- 
tionship between real economic activity and quarterly money growth, success can be measured in terms of the reduction in the variability of both the quarterly money growth series and in economic activity.

\section{Monev Crowth Simulatons: Bot Jentins Multipher Forecasts}

The money multiplier forecasts generated from the BJ model, reported in table 1 , are used to simulate money growth from January 1980 to December $1982 .^{9}$ Table 3 summarizes the results using these forecasts and the control procedure described above. The posited MI growth targets for 1980,1981 and 1982 are 5.25 percent, 6.00 percent and 4.00 percent, respectively.

The results in table 3 indicate that, on average, the simulated level of $\mathrm{M} I$ is close to the desired amount. The largest discrepancies occur in early 1980, the period of the special credit controls. For example, the simulated level of M1 in April 1980 is more than $\$ 8$ billion below the targeted level. As explained, the monthly growth rates for the simulated series are expectedly erratic under this control procedure. Compared with the actual MI growth rate data in table 2, however, the pattern of growth rates is quite different. For example, in 1980, actual M1 increased during the first two months at an average rate of 10.7 percent. During the next two months, it declined at an average rate of 11.7 percent. From April to August, Ml steadily increased at an average rate of 15.8 percent and, during the last of the year, increased at a 6.25 percent rate.

\footnotetext{
It has been argued that the actual pattern of the multiplier and, therefore, the money stock wonld have been different had the Federal Reserve operated under a monetary control procedure like the one discussed in this study. Two points need to be made: First, this argument can be raised against all simulation experiments. Their purpose, after all, is to investigate the outcomes under different sets of conditions. There is generally no way to determine the validity or usefulness of this criticism.

Second, this argument is based on the assumption that multiplier forecasts are rendered useless by the endogeneity of the monetary base during the multiplier forecasting period. This problem has been examined by lindsey (and others) and found to affect the reliability of the type of multiplier forecast procedures enployed here. In a recent paper, however, Brunner and Meltzer have shown that these assertions are highly questionable. For alternative views, see David Lindsey and others, "Monetary Control Experience Under the New Operating Procedures, "in New Monetary Control Procedures, Vol. 2, Federal Reserve Staff Study (February 1981); and Kanl Brunner and Allan H. Meltzer, "Strategies and Tactics for Monetary Control," in CarnegieRochester Conference Series, Vol. 18 (1983), pp. 59-104.
}

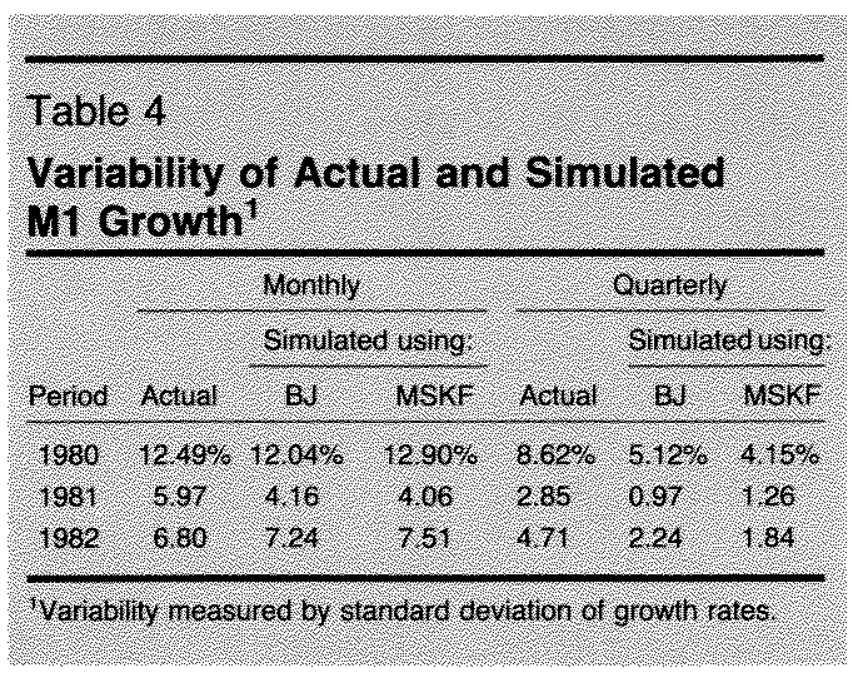

Simulated MI based on the BJ multiplier forecasts increases at a slower 8.2 percent rate in early 1980 , then declines at a 10.5 percent rate from February through April. In May, the simulated M1 figure rebounds sharply as the procedure attempts to offset the errors of the previous two months: during the period April to August, simulated M1 growth averages 16.7 percent. Finally, in contrast to the 6.25 percent rate of actual M1 growth during the final four months of 1980 , simulated Ml averages only a 0.64 percent rate of growth.

The volatility of the simulated monthly growth rates continues throughout the sample. For comparison, the variability of the actual and simulated money growth series are reported in table 4 . In each year, the variability of the simulated growth rate series is about the same as the actual growth rate of money.

Reducing the monthly variability of money growth, however, is not the goal of the procedure. One aim is a reduction in quarterly growth rate variability. Judging from the evidence in table 3 , the approach used here does exactly that ${ }^{10}$ Note that throughout the period the swings in quarterly growth rates are reduced. For instance, actual $\mathrm{M} 1$ growth ranges from 16.94 percent in III/1980 to -3.84 percent in IV/1980. The corresponding figures for simulated M1 growth are less volatile, varying between 12.15 percent in $111 / 1980$ and 0.65 percent in IV/1980.

\footnotetext{
${ }^{10}$ It should be noted that the first-quarter growth rates of the simulated series are measured from the actual level of money in the previous quarter. This reflects the common "foregiveness principle" of adjudging money growth from its actual level as opposed to the desired level.
} 


\section{Table 5}

\section{Simulating M1 Growth Using MSKF Multiplier Forecast: January 1980-December 1982 (seasonally adjusted)}

\begin{tabular}{|c|c|c|c|c|c|c|c|}
\hline \multirow[b]{2}{*}{ Period } & \multirow{2}{*}{ Targefed } & \multirow{2}{*}{ Aroual } & \multirow{2}{*}{ 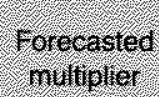 } & \multirow{2}{*}{$\begin{array}{l}\text { Simulated } \\
\text { hase? }\end{array}$} & \multirow{2}{*}{ simurateg } & \multicolumn{2}{|c|}{ Simulated M/ growth rale } \\
\hline & & & & & & worraly & ovrarery \\
\hline 1,1980 & 53007 & 25855 & 2.5689 & 81508 & 63917 & $8.58 \%$ & \\
\hline $2 / 1980$ & 3023 & 2.6026 & 25944 & 1.1512 & 3936 & 602 & $4.81 \%$ \\
\hline $3 / 1980$ & 3940 & 25789 & 2.6009 & 1516 & 000.6 & 874 & \\
\hline 41980 & 3957 & 25235 & 2.5796 & 1544 & 387 & -10.25 & \\
\hline 5.1980 & 1997.4 & 25260 & 2.5244 & 1674 & $897 \%$ & 3854 & 3.40 \\
\hline 6.1960 & 899 & 25373 & 25260 & 1560 & 4009 & 3.67 & \\
\hline 71960 & 1008 & 2.5508 & 2.6645 & 156. & 403 & $7 / 4$ & \\
\hline $8 / 1980$ & 402.5 & 26716 & 2.5476 & 1506 & 406.8 & 9.6 & 1068 \\
\hline 91980 & 4042 & 2586 & 25688 & 157.4 & 4062 & 0.4 & \\
\hline 1091960 & 4060 & 25837 & 25799 & 574 & 4068 & 066 & \\
\hline 111960 & 4077 & 25605 & 25834 & 1579 & $4041 \%$ & $-7,03$ & 078 \\
\hline $12 / 1980$ & 4092 & 25514 & 25626 & 1568 & 4076 & 1714 & \\
\hline 111961 & 4161 & 25612 & 255624 & 1630 & 475 & 1044 & \\
\hline 21981 & $416 / 1$ & 26698 & 25605 & 1603 & 406 & 624 & 462 \\
\hline 31981 & 4202 & 25853 & 25600 & $16 \% 6$ & 4228 & 9.52 & \\
\hline 41981 & 4222 & 25964 & 25640 & 1648 & 4242 & 405 & \\
\hline 5.1981 & 4243 & 2.5870 & 25954 & 1655 & 4229 & 3.74 & 387 \\
\hline 671981 & 426.6 & 25780 & 2.5876 & 1646 & $(4248$ & 5.84 & \\
\hline 7,1981 & 4284 & 25806 & 25796 & 166,1 & 4886 & 1044 & \\
\hline 81981 & 480.5 & 25848 & 25805 & 1668 & 481 & 7.35 & 650 \\
\hline $9 / 196$ & 4326 & 25834 & 25840 & 1674 & 1825 & (3. 88 & \\
\hline 10.1981 & $154 \%$ & 25807 & 25834 & 166.3 & 4642 & 494 & \\
\hline 11,1981 & 4568 & 25824 & 2.5810 & 1602 & 4371 & 8.03 & 622 \\
\hline 12,1981 & 439.0 & 25018 & 25822 & 1700 & 4106 & 10.12 & \\
\hline VI 1982 & 4420 & 26096 & 25941 & 1706 & 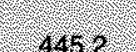 & 1755 & \\
\hline 21982 & 4,35 & 25866 & 26083 & 1700 & 4308 & -10.59 & 6.00 \\
\hline 31982 & 4449 & 25826 & 25880 & 1719 & 44,0 & 1212 & \\
\hline 41982 & 1464 & 25689 & 25830 & 1728 & 8440 & 2.0 .18 & \\
\hline 51982 & 4479 & 25661 & 25699 & 1743 & 4472 & .9 .13 & 269 \\
\hline 0,1082 & 4,98 & 25615 & 25664 & 475,1 & 4867 & $-1,26$ & \\
\hline 7,71982 & 450.8 & 25542 & 25525 & 1766 & 451. & 1245 & \\
\hline 811982 & 4523 & 25603 & 25541 & $17+1$ & 4564 & $(6.2)$ & 698 \\
\hline $9 / 1982$ & 4538 & 25739 & 25599 & 1772 & 4561 & 753 & \\
\hline 10,1982 & 4562 & 25881 & 2.5725 & 7770 & 4680 & 5.02 & \\
\hline $11 \times 1982$ & 4567 & 25987 & 25872 & 176.5 & 4586 & 198 & 4.86 \\
\hline 1211982 & 4582 & 26088 & 25981 & 0.176 .4 & 460 & 364 & \\
\hline
\end{tabular}

Billons of dollars:

This reduction in quarterly money growth volatility is made clearer in table 4 . There we see that the volatility of the quarterly money growth derived from the BJ multiplier forecasts is appreciably smaller than the actual. In fact, in 1981 and 1982 , the volatility of simulated quarterly M1 growth is less than one-half that of actual M1 growth. Thus, in terms of reducing quarterly fluctuations in money growth, the control procedure using the BJ multiplier forecasts is quite successful.

\section{Money Growh Simulations: MSK Mullipler Forecuss}

The outcome from using the MSKF multiplier forecasts to simulate M1 growth is reported in table 5 . Similar to the results using the BJ multiplier forecasts, the simulated $\mathrm{M} 1$ growth rates in table 5 exhibit a large degree of monthly variation. Again, in contrast to actual M1 growth, the distribution of monthly growth rates reveals the procedure's attempt to correct devia- 
tions from the desired $\mathrm{Ml}$ path. As reported in table 4, the monthly money growth derived from the MSKF forecasts is more variable than either actual money growth or the BJ simulations in 1980 and again in 1982.

This monthly volatility, however, again translates into a more stable pattern of quarterly Ml growth. Recall that, during the second half of 1980 , simulated MI growth based on BJ multiplier forecasts varied from 0.65 percent to 12.15 percent. Over this period, the MSKF-based figures range from 0.78 percent to 10.59 percent. As shown in table 4, quarterly $\mathrm{M} 1$ simulated using the MSKF forecasts is less volatile than that using the BJ multiplier forecasts in 1980 and 1982. This suggests that the MSKF approach provides a steadier path of quarterly money growth than the BJ approach.

The evidence indicates that stable quarterly money growth can be achieved by making use of the multiplier forecasting techniques implemented here. Based on our empirical results, the simulated quarterly money growth series were, on average, about 50 percent less variable than actual M1 growth during the past few years. Moreover, the simulated series generally came quite close to hitting the desired M1 growth target. As shown in table 6, both simulated money series missed the annual growth targets by only one percentage point, on average.

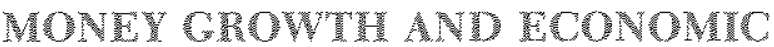 ACring}

Large fluctuations in quarterly MI growth have led some observers to conclude that the pattern of economic activity during the $1980-82$ period is attributable largely to volatile monetary policy actions. In deed, empirical evidence for the United States and other countries suggests a close association between substantial short-run declines in money growth from its trend and the pace of economic activity. ${ }^{11}$ During

\footnotetext{
"Historical evidence on this point for the United States is presented in Clark Warburton, "Bank Reserves and Business Fluctuations," Journal of the American Statistical Association (December 1948), pp. 547-58; Milton Friedman and Anna J. Schwartz, "Money and Business Cycles," Review of Economics and Statistics (Supplement: February 1963), pp, 32-78; and William Poole, "The Relationship of Monetary Decelerations to Busi" ness Cycle Peaks: Another Look at the Evidence," Journal of Finance (June 1975), pp. 697-712. An analysis of more recent data for the United States along with several other countries can be found in Dallas S. Batter and R. W. Hafer, "Short-Runi Money
}

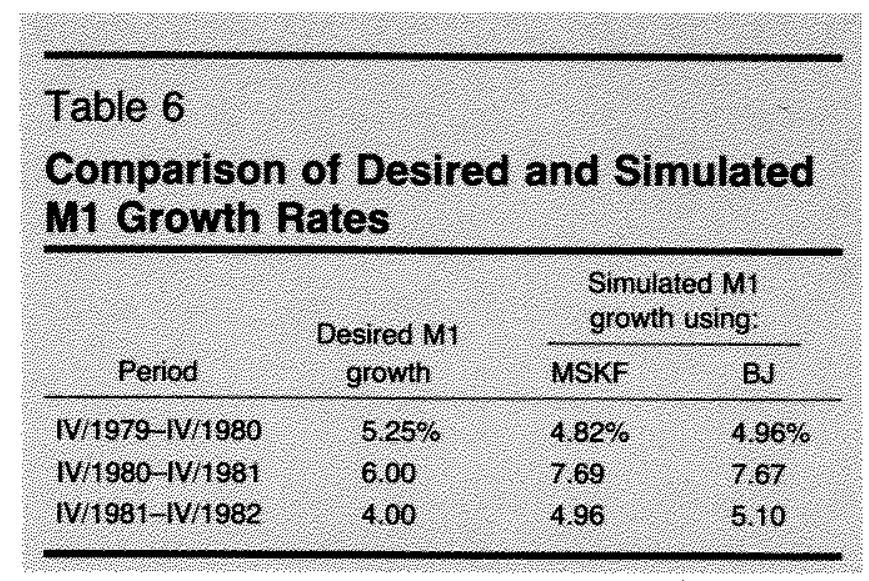

our sample, such deviations occurred in early 1980 and again in 1981. In this regard, reducing money growth fluctuations, everything else equal, should produce more stable economic growth. To examine this hypothesis, the following experiment was conducted: First, a standard, St. Louis type of reduced-form equation for nominal GNP growth was estimated over the period U/1960 to IV/1979. Then, using the estimated coefficients, GNP growth was simulated for the period I/1980 to IV/1982. Three simulation runs were made: one with actual M1 growth, one with the posited path of M1 and one based on Ml growth from the MSKF money growth simulations. (The BJ simulations are omitted because they were so similar to the MSKF.)

The simulated GNP growth rates for each experiment are reported in table $7 .^{12}$ The volatility of actual Ml growth is evident in the consequent fluctuations of GNP growth, especially in 1980 when GNP growth fluctuated from 6.81 percent to 12.69 percent. For the whole period, nominal GNP growth simulated with actual money growth averages 10.46 percent with a standard deviation of 1.94 percent.

The pattern of GNP growth simulated under the posited M1 path of 5.25 percent growth in $1980,6.0$

Growth Fluctuations and Real Economic Activity: Some Implica tions for Monetary Targeting," this Review (May 1982), pp. 15-20.

${ }^{12}$ The equation used to generate the simulations is (t-statistios in parentheses):

$$
\begin{aligned}
& \dot{\mathrm{Y}}_{\mathrm{t}}=2.507+1.052 \stackrel{4}{\Sigma} \quad \beta_{\mathrm{i}} \dot{\mathrm{M}}_{\mathrm{t}-\mathrm{i}}+0.068 \stackrel{4}{\Sigma} \quad \widehat{\mathrm{o}}_{\mathrm{i}} \dot{\mathrm{E}}_{\mathrm{t}-\mathrm{i}} \\
& \begin{array}{lll}
\text { (2.14) } & (5.34) \mathrm{i}=0 \quad(0.68) \mathrm{i}=0
\end{array} \\
& \overline{\mathbf{R}}^{2}=0.33 \quad \mathrm{SE}=3.52 \quad \mathrm{DW}=1.95
\end{aligned}
$$

where $\dot{Y}$ is nominal GNP growth, $\dot{M}$ is the growth of $M 1$ and $\dot{E}$ is the growth of high-employment government expenditures. The equation is estimated for the period I/1960-IV/1979 using a fourth-order Almon polynomial lag for each of the explanatory variables with endpoints constrained. All simulations use actual E. 


\section{Table 7}

\section{Simulated Quarterly GNP Growth Rates: 1/1980-IV/1982}

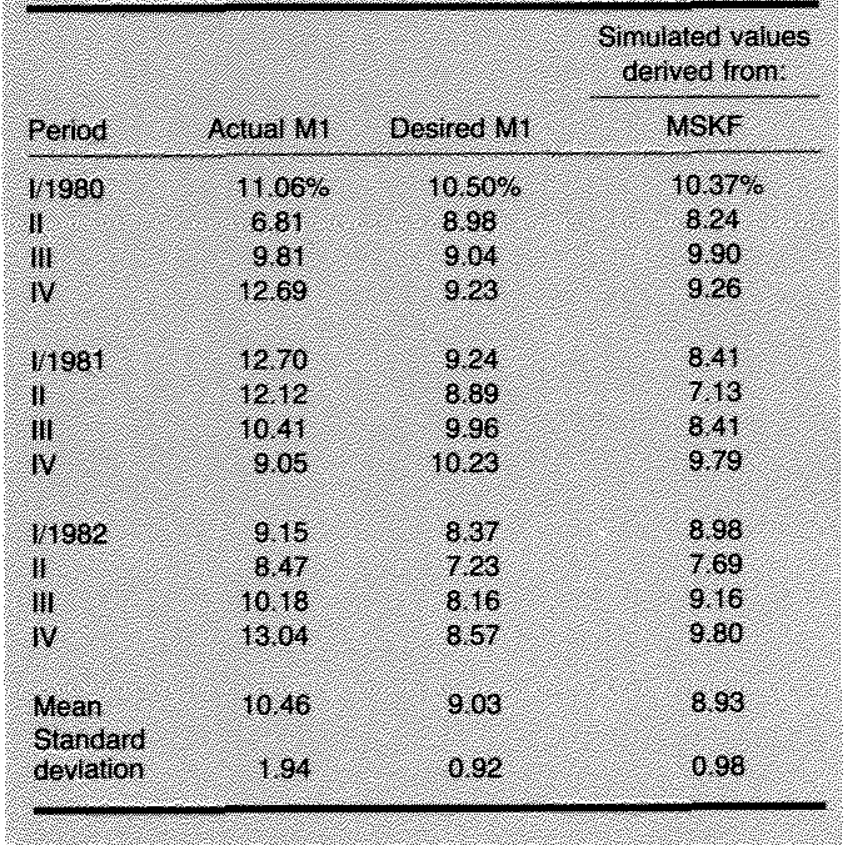

percent growth in 1981 and 4.0 percent growth in 1982 is very different from that simulated with actual $\mathrm{M} 1$ growth. For one thing, the average GNP growth simulated with actual money is almost 1.5 percentage points above that simulated with the desired path. It is only in II/1980 and IV/1981 that GNP growth based on actual money is less than GNP growth based on desired money. In addition to the difference in mean growth rates, there is also a sizeable difference in the volatility of GNP growth under the alternative simulations. As measured by the standard deviation of GNP growth, the simulations with actual money show more than twice the volatility than the simulations with desired money yield.

Comparisons between simulations using actual and desired money growth presumes that the desired money growth easily can be achieved. As we have seen, however, the Fed cannot totally control money growth from one quarter to the next. How serious a problem is this? Would this lack of precise control make it difficult to achieve a less volatile GNP growth objective?
To examine this issue, the GNP equation was simulated using the M1 growth rates that resulted from the MSKF money multiplier forecasting control procedure. These simulated GNP growth rates are shown in the third column of table 7 . There is surprisingly little difference between the GNP growth simulated using desired $\mathrm{M} 1$ growth and $\mathrm{M} 1$ growth resulting from the forecast/control procedure. The average level of GNP growth under the desired M1 growth scenario is 9.03 percent, compared with 9.08 percent under the MSKF procedure. The standard deviation of simulated GNP growth is less than one percent in both cases - about one-half that associated with actual M1 growth. In addition, the simulated GNP path using the quarterly growth of money derived from the MSKF forecast procedure usually is within one percentage point of the simulated GNP path using desired MI growth.

\section{SUMMART AND CONOLUSTON}

This paper has examined two alternative procedures to forecast the MI multiplier. The multiplier was forecast one period ahead for the 1980-82 sample period using both a Box-Jenkins and a Multi-State Kalman Filter forecast procedure. The evidence from the multiplier forecasts shows the MSKF procedure to be an improvement over the BJ procedure. For example, the MSKF yielded a root-mean-squared error about 9 percent smaller than the BJ procedure for the whole period, with even greater reduction in forecast error in 1981 and 1982.

Both forecasts of the multiplier then were used to simulate MI growth. These simulations resulted in volatile monthly growth rates, but relatively stable quarterly growth rates. There was, in fact, little difference between the simulated $M 1$ growth rates, suggesting that forecasting the multiplier with great accuracy may not be as important as aiming for a steady long-run growth rate.

The paper also examined the importance of money stock control by simulating GNP growth under the hypothetical desired path, as well as the Ml growth simulated under the MSKF forecast/control procedure. There was only a minor difference in these simulations; quarterly GNP growth usually did not differ by more than one percentage point. This indicates that the money multiplier forecast/control procedure used in this article could be successful in achieving more stable GNP growth. 